\title{
HEILSHISTORIES-VERBONDSMATIGE PREDIKING TEENOOR EKSEMPLARISTIESE PREDIKING
}

\author{
N. Droomer \\ Geref. Kerk Die Kandelaar \\ PRETORIA
}

\begin{abstract}
When preparing a semmon on an historical tex from Scripture, several approaches can be followed, inter alia an exemplaristic or a redemptive-historical approach. The central problem, however, is the way in which the acts of biblical figures should be interpreted and treated in the sermon. It is contended that on the one hand the approach should not be focused on the acts of biblical figures as being examples to be directly applied to contemporary circumstances, as this approach will probably result in 'exemplaristic' preaching.
\end{abstract}

On the other hand, the redemptive-historical method of preaching does not fumish a conclusive answer either. Although this method focuses on God's nevelation in biblical history, it seldom does justice to the role that a specific biblical figure plays in the paricular pericope that is analysed in the sermon.

In this anticle it is angued that the covenantal approach should rather be followed without neglecting the redemptive-historical aspect. By utilizing this approach the emphasis will fall on the reactions of God's people as well as on God's revelation in that particular stage of history. This approach also implies the possibility of a natural application of historical facts, thus clearly indicating guidelines as to what God expects from the church of today.

\section{INLEIDING}

By geleentheid is 'n sterk pleidooi gelewer dat Gereformeerde prediking uit die historiese gedeeltes van die Skrif heilshistories moet wees (D'Assonville, 1961:13-16). Hierdie pleidooi word saamgevat in sy boek Die dwaasheid om te preek (D'Assonville, 1976:57-69). Dit is egter te betwyfel of gemeentes dikwels genoeg vanuit die historiese gedeeltes van die Ou Testament die gesagvolle Woord van God hoor. Op grond van radio-oordenkings, preke in Die Kerkblad, en gepubliseerde preke kan beweer word dat baie predikante moeite ondervind om die verhalende gedeeltes van die Skrif tot hulle reg te laat kom.

Dit gaan dus in hierdie artikel oor die vraag hoe daar gepreek moet word wanneer verhalende gedeeltes van die Skrif as teksgedeelte gekies word - heilshistories of eksemplaristies? Ook kan die vraag gestel word of dit nie heilshistories-verbondsmatige prediking is wat die klem reg lê nie. 
Die beredenering van hierdie onderwerp word voorts onder die volgende hoofde behandel:

- Die eksemplaristiese benadering en besware daarteen.

* Die heilshistoriese benadering en besware daarteen.

- Heilshistories-verbondsmatige prediking as antwoord.

- Enkele riglyne vir heilshistories-verbondsmatige prediking oor die historiese gedeeltes van die Skrif.

* Slotsom.

\section{DIE EKSEMPLARISTIESE BENADERING EN BESWARE DAARTEEN}

\subsection{Die term eksemplaristiese prediking}

Die term eksemplaries is vir die eerste maal deur Holwerda (1953:82) gebruik. Sedertdien het hierdie term egter algemeen-gebruiklik geword. Onder die term eksemplariese prediking is verstaan die preekmetode wat figure of gebeurtenisse uit die historiese gedeeltes van die Skrif op so 'n wyse tot voorbeelde vir die hedendaagse luisteraars voorhou, dat die verbande waarin so 'n persoon of gebeure staan, buite rekening gelaat word. Die én voortgaande openbaring van God word opgebreek in talle losstaande geskiedenisse. Jonker (1976:64) sê dat hierdie preekmetode die geskiedenisse van die volk Israel, van die aartsvaders en die profete, van rigters en konings, van die mense wat Jesus ontmoet het en die apostels en wat hulle gedoen het, gebruik soos 'n arsenaal van voorbeelde. Hierdie voorbeelde moet die mens van vandag aanmoedig of waarsku. Dit is iets anders as wanneer hierdie geskiedenisse so sou behandel word dat dit sigbaar word wat God van Homself daarin openbaar. Sou laasgenoemde gebeur, sou dit vanself meebring dat ook die mens 'geopenbaar' word in die lig wat van God afstraal, maar in plaas hiervan word die aandag gevestig op die mense (my kursivering - N.D.) in daardie geskiedenisse. Die historiese figure word getipeer as voorbeelde vir ons en op allerlei maniere word verbindingslyne tussen hulle en ons getrek.

Verkieslik behoort van 'n eksemplaristiese hantering van die verhalende gedeeltes van die Bybel gepraat te word. Dit is die term wat Schilder (1983:19) gebruik wanneer die eksemplariese behandeling van Bybelfigure tot'n metode en maatstaf word. Daar is immers, soos later duidelik sal word, 'n regmatige plek vir die eksemplariese element wanneer uit historiese gedeeltes van die Skrif gepreek word. 


\subsection{Voorbeelde van eksemplarisme}

Talle voorbeelde word deur Van 't Veer (1944:140) gegee om duidelik te maak hoe hierdie metode toegepas word. Die volgende twee is genoegsaam om aan te toon wat bedoel word:

Die vriendskap van Dawid en Jonatan word in die preek behandel as 'n voorbeeld van alle ware vriendskap onder Christene. Daarby word gestel dat sulke ware vriendskap alleen in Christus gegrond kan wees, dit wil sê as ons tesame vriende van Jesus is.

Die gebed van Hanna word in die preek aan ons voorgehou as 'n voorbeeld hoe ons met ons smart na die kruis van Christus moet gaan. Die verhoring van Hanna se gebed is 'n bewys dat dit help om te bid. Strydom (1989:113-140) gee verdere voorbeelde.

\subsection{Besware teen eksemplaristiese prediking}

Greidanus (1970:65-120) gee 'n samevatting van die mees algemene besware teen eksemplaristiese Skrifgebruik:

- Bybelse figure word biografies in preke behandel.

- Sodanige preke is nie Christosentries nie, maar mensgerig en moraliseer, dit wil sê dit word ' $n$ sedeles wat draai om die geloof of ander optrede van byvoorbeeld ' $n$ Abraham of 'n Moses.

- Preke word psigologiese ontledings van Bybelfigure.

- Die Skrif word opsioneel: die preek kon net sowel oor 'n figuur uit die Koran gegaan het.

- Historiese stof word vergeestelik.

- In sodanige preke word oral in die Ou Testament tipes van Christus gevind.

- Dit subjektiveer. die sogenaamde "kenmerken-prediking".

- Daar is 'n dualisme van uitleg en toepassing.

Gevolgurekking: Bybelskrywers of Bybelfigure word aan die gemeente op 'n verkeerde manier as voorbeelde voorgehou.

Die vernaamste besware teen 'n Bybelgebruik wat eintlik sonder meer 'n historiese gelykteken tussen die Bybelse persone en -geskiedenis en ons plaas, moet van nader beskou word. 


\subsubsection{Eksemplarisme misken die eie aand van verhalende stof}

Geskiedenisgedeeltes in die Skrif kan nie op dieselfde wyse uitgelê word as gelykenisse nie - dit moet behandel word as feite uit die geskiedenis, as deel van 'n groter geheel, (Holwerda, 1953:87).

Grosheide, (1929:195) wys daarop dat die Bybel éen verhaal is, geïnspireer deur één Goddelike outeur, die Heilige Gees, en die feite uit die geskiedenis is vanuit 'n bepaalde oogpunt gekies, voorgestel en georden. Daarom is ons nie geregtig om 'n deel daarvan te neem en dit geïsoleerd van die geheel te behandel nie. Holwerda (1953:93) noem dit ' $n$ "atomistiese behandeling" van die heilsgeskiedenis, want die een groot heilsgeskiedenis word in fragmente opgebreek en behandel.

Trimp (1986:26) tipeer Bybelse geskiedenis as die verhaal van die konkreet-historiese pad wat God met sy volk hier op aarde gegaan het. Dit raak sowel sy gang as sy omgang met die mens. Wie erns maak met die historiese aard van die gedeelte, vra tog allereers na die eintlike bedoeling van die feit wat daar meegedeel is, met ander woorde wat wil God aangaande Homself in hierdie gedeelte bekendmaak.

Hier kan gedink word aan die voorbeeld van Hanna: dit is vanselfsprekend dat gelowiges met hulle probleme na God toe moet gaan, maar om dit te staaf, mag nie sommer na Hanna se gebed vir 'n seun gegryp word nie. So 'n toepassingswyse hanteer die geskiedenis asof dit 'n gelykenis is. Hanna se gebed en God se verhoring daarvan is tog verbonde met Israel se geskiedenis en Samuel se taak daarin as rigter en hierdie enger en wyer Skrifverband behoort (en mag) tog nie verwaarloos word nie.

Schilder (1974:41) wys tereg op die verreikende konsekwensies van hierdie tipe Skrifgebruik wanneer die mens die Skrif gebruik om sy ideologie te rugsteun. So misbruik die teologie van die rewolusie ook vandag inderdaad die Skrif. Jesus, wat die tafels van die geldwisselaars omgooi, word sonder meer die voorbeeld van die rewolusionêr en jongmense vind in sy optrede regverdiging vir allerhande ondermynende aksies en opruiende betogings teen die wettige owerheid. Ook word verwys na die profete, byvoorbeeld die vlymskerp kritiek wat Amos teen die kapitalistiese leiers van Samaria uitgespreek het. Volgens hierdie Skrifgebruik kry die vloekpsalms nuwe aktualiteit in die stryd teen alle verdrukkers van minderhede, teen kolonialiste, teen die groot industriebase.

\subsubsection{Eksemplarisme misken die feit dat Bybelse geskiedenis heilsgeskiedenis is}

Trimp $(1986: 28,29)$ verduidelik die term heilsgeskiedenis deur te sê dat die Ou Testament ons God laat sien as die Vader van Jesus Christus; Hy is die Skepper wat 
besig is om sy Seun te stuur as Verlosser. Hierdie benaderingswyse impliseer die Cliristologiese sentrering en verankering (kursivering N.D.) van alle Ou-Testamentiese verhale. Nooit sou een van hulle gebeur het of beskrywe gewees het as daar nie in God die voorneme was om te kom tot die dag, wat Johannes 1:14 bedoel, dat Hy deur sy Seun by die mense sou kom woon nie. Trimp verklaar dit so: "In Christus vinden alle verhalen (van die Ou Testament) hun sin, hun rust, hun verklaring en hun draaggrond." By geleentheid het Christus self gesê dat die Skrifte om Hom draai: "Dit is die Skrifte wat van My getuig" (Joh. 5:39). In sy gesprek met die Emmausgangers wys Christus hoe Moses en al die profete op Hom betrekking het (Luk. 24:27).

Die Nuwe-Testamentiese gemeente kan nie anders as om die Ou Testament Christologies, of teosentries, te lees nie. Genesis 3:15 dring ons daartoe, want Genesis 3:15 laat op alles wat in die hele Skrif daarna volg, die lig val van die stryd tussen die vrouesaad en die slangesaad, tussen Christus wat aan kom is in die wêreld, en Satan (Van't Veer, 1944:149).

Hierdie Christologiese eenheidstema van die Bybelse geskiedenis word bevestig deur Openbaring 12: hier word die geskiedenis van die Ou en Nuwe Testament getipeer as die worsteling van die swanger vrou wat haar Seun moet baar en gebaar het, en die draak wat Hom wil verslind (Van 't Veer 1944:149). As gevolg van hierdie duidelike sleutel wat die Bybel self as sy verklaring gee, kan ons geen enkele Bybelse figuur gaan losmaak van die groot stryd tussen Christus en Satan nie. Elkeen se plek is Christologies bepaal, of hy nou 'n medewerker of ' $n$ 'teëstander' in daardie stryd is.

Schilder (1983:15) toon aan hoe die vaders die Ou Testament in die Heidelbergse Kategismus (Sondag 6, antw. 19) Christologies só benader: daar word naamlik gesê dat ons die Middelaar ken uit die heilige Evangelie "wat God self eers in die Paradys geopenbaar het en daarna deur die heilige aartsvaders en profete laat verkondig en deur die offerandes en ander seremonies van die wet vooraf laat afbeeld het en eindelik deur sy eniggebore Seun vervul het ...". Daarop voeg hy by:

Eigenlijk toch is in deze uitspraak de basis gelegd voor heel het vak der openbaringsgeschiedenis en de weg gewezen tot het heilshistorisch verstaan van de Schriften ... Wie dit antwoord belijdt, weet tegelijk: het gaat au in het Oude Testament niet meer om Abraham, of om David, of om welke vrome dan wel goddeloze ook. Het gaat niet om mensen als voorbeelden van goed of kwaad, exempelen van deugd of ondeugd, het gaat om de openbaring van de Middelaar ...

Om 'n enkele voorbeeld te noem: Agab moet gesien word soos die Skrif hom aan ons voorhou, naamlik as teokratiese vors in die stryd tussen God en Satan, waarin dit om die Christus gaan (vgl. Van "t Veer, 1944:149).

Odendaal (1989:143 e.v.) wys tereg daarop dat die geskiedenis van God se heil in die 
Ou Testament ook as verbondsgeskiedenis getipeer kan word. Verbondsgeskiedenis lê die aksent daarop dat God Homself openbaar en sy heil skenk in die weg van sy konkrete omgang met mense, 'n omgang wat in die Bybel getipeer word as 'n omgang soos dié van 'n man en vrou in die huwelik. As die heilsgeskiedenis ook as verbondsgeskiedenis gesien word, dan bewaar laasgenoemde aksent ons daarvan om die mens in die heilsgeskiedenis oor die hoof te sien (Trimp, 1986:40).

\title{
2.33 Eksemplarisme ignoreer die voortgang in die heilsgeskiedenis
}

\begin{abstract}
Alles in die Skrif is nie neergeskryf aan die einde van God se heilshandelinge nie. Die hele Ou Testament is met name geskryf in 'n situasie van verwagting van die koms van die Messias en dra dus ' $n$ ander karakter as die Nuwe Testament, wat geskryf is na die volheid van die tyd aangebreek het. (Jonker, 1976:52.)
\end{abstract}

God se openbaring in Christus is soos 'n blomknop wat geleidelik oopvou, sodat die openbaring duideliker word. Hebreërs 1:1 stel dit soos volg: "Nadat God baie keer en op baie maniere in die ou tyd gespreek het tot die vaders deur die profete, het $\mathrm{Hy}$ in hierdie laaste dae tot ons gespreek deur die Seun." Daarom het Schilder (by De Vries, 1983:167) gelyk as hy die algemeen-hermeneutiese en homiletiese beginsel vir die prediking oor historiese stowwe soos volg neerlè: "Een preek over een "historische stof is dan alleen préék, als zij Gods werk van zelfopenbaring ter verlossing in Christus aanwijst, gelijk dat werk voortgeschreden is tot op dat bepaalde 'tijdsgewricht', waarin de tekst ons inleidt (kursivering van K. Schilder) en wanneer zij dat bepaalde 'punt' van ontwikkeling van Gods werk, zoëven genoemd, in verband zet met heel de 'lijn' van dit werk (al de eeuwen al de Schriften door)". In dieselfde gees stel Kapteijn (1988:101) dat ons Abraham in sy tyd en lewensomstandighede nie met byvoorbeeld Moses kan gelykstel nie, want by Moses het die geskiedenis van God se openbaring verder voortgegaan: Moses staan 'n ent verder op die een lyn van God se heilshistorie - die geskiedenis van sy koms in Jesus Christus.

Wanneer die voortgang in die heilshistorie nie raakgesien word nie, word 'n deel van die teks maklik uit sy geheel uitgelig en by twee totaal verskillende Skrifgedeeltes presies dieselfde dinge gesè oor bepaalde gesteldhede by die betrokke persone wat daar beskryf word. Mattteus 11:1-6 handel byvoorbeeld oor die twyfel van Johannes die Doper; Johannes 20:24-29 oor die twyfel van Thomas, maar omdat die verband met die besondere hoofstuk sowel as die verband met die geheel van die heilshistorie verwaarloos word, word dan op dieselfde manier oor beide tekste gepreek: Jesus verlos van alle twyfel (Holwerda, 1953:92 e.v).

Wie egter met die voortgang in die heilshistorie rekening hou, sien dat die twyfel by Johannes die Doper anders is as by Thomas, omdat hy op ' $n$ ander moment in die 
verloop van God se heilsgeskiedenis twyfel as Thomas. Laasgenoemde twyfel ná die opstanding van die Here; daarom moet die oplossing en toepassing ook anders wees (vgl. Holwerda, 1953:91). As dit in 'n preek gaan oor Abraham se geloofsbeproewing (Abraham se offer van Isak op Moria - Gen. 22) en dit gaan in 'n preek oor Matteus 15:21-28 (die Kananese vrou) ook oor geloofsbeproewing, dan kan ons dieselfde preek kry met dieselfde toepassing, terwyl in die twee Skrifgedeeltes totaal verskillende feite in 'n totaal verskillende verband ter sprake is (D'Assonville, 1962:25,26; De Vries, 1983:159,60).

\subsubsection{Eksemplarisme neig tot verregaande tipologisering}

Holwerda (1953:94) en sy geesgenote (o.a. Van der Waal, 1974:234) wys op die geweldige belang daarvan dat die Ou Testament tipologies gelees moet word.

Die woord tipologie is afgelei van die Griekse woord tunos in 1 Korintiërs 10:6. Daaruit is dit duidelik dat in 'n bepaalde gebeurtenis of persoon of instelling iets vooraf afgebeeld is wat later herhaal word. Die verlossingswerk van die Here in die Nuwe Testament word beskrywe volgens 'n bepaalde grondplan of bloudruk of model wat reeds in 'n Ou-Testamentiese persoon of instelling of gebeure neergelê was. Trimp (1986:50-54) wys daarop dat 'n mens in die Ou Testament 'vooraf-afbeeldings' of tipes vind van wat later in die Bybel kom. So praat die Heidelbergse Kategismus (Sondag 6, antwoord 19) ook van die 'vooraf-afbeelding' van die Middelaar Jesus Christus in die Ou Testament. In so 'n geval word die bepaalde Ou-Testamentiese model 'tipe' van die Nuwe-Testamentiese gebeure genoem. In die Ou Testament kan 'n mens reeds die struktuur van die latere sien. 'n Voorbeeld is dat Johannes die Doper Christus in Johannes 1:19 "die Lam van God wat die sonde van die wêreld wegneem", noem. Vooraf is Christus as Lam van God in die Ou Testament afgebeeld deur die paaslam wat by die uittog uit Egipte die sondes van die volk Israel moes versoen (vgl. Eks. 12).

Van der Walt (1989:53 e.v.) gee in sy artikel "Teologiese tipologie: 'n Homiletiese sleutel vir die prediking van die Ou Testament", drie Nuwe-Testamentiese riglyne om te ontkom aan die gevaar van valse tipologiese prediking, naamlik wanneer die Nuwe Testament praat van vervulling ( $\pi \lambda$ npnS), van voltooiing ( $\tau \in \lambda \in \omega \zeta)$ en voleinding

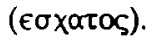

Wanneer die Nuwe Testament die formule "... sodat vervul mag word wat geskrywe is ..." gebruik, wys dit op 'n vol-ler-wording van die trou van God (Van der Walt. 1989:57). Hy verwys na Lammens wat sê dat tipologie wil laat uitkom "de in de geschiedenis werkzame constante van de trouw van Jahwe die Zijn verbond gedenkt en 
Zijn ene heilswerk voortzet in telkens nieuwe daden, die de vroegere overtreffen". So kan die prediking lyne trek vanuit die Ou Testament na die Nuwe-Testamentiese Christelike gemeente (gelowiges). (Vergelyk verder by van der Walt hoe die doelformule en die voleindingformule, soos hy dit noem, help om tot die regte tipologiese prediking van die Ou Testament te kom.)

Hierdie tipologiese aard van die Ou Testament laat ons egter nie toe om oral in die Ou Testament in biografiese besonderhede of in uiterlike toevallige ooreenkomste tipes te soek nie - iets wat baie predikante in die verlede al gedoen het. Dan word die hout wat in die Marawaters gegooi word, tipe van die kruis van Christus wat die bitterheid uit ons Mara-waters moet wegneem. Soms word die rooi tou wat uit die venster van Ragab afhang (Jos. 2:18) sonder meer tipe van die reddende bloed van Christus gemaak. Van 't Veer (1944:138-145) noem talle sulke voorbeelde van tipologiese afleidings wat predikers self vervaardig het.

Daarenteen word by Schilder (1983:23) die juiste voorbeeld van tipologie gevind as hy sê dat Salomo se koningskap in die Skrif 'n voor-afbeelding van die ware Vredekoning, ons Here Jesus Christus, gee. Daar is by Salomo 'n armoede wat roep na die koms van Hom wat meer is as Salomo. Dit moet egter ook nie misgekyk word nie dat die komende Christus ook in Salomo sy glorie en sy weldade voorafskadu.

As die Ou Testament tipologies benader word, en die Ou Testament en die Nuwe Testament daarby die gids is, kan dit nie anders as dat daar sinteties, Christosentries en verbondsmatig gepreek sal word nie. Terselfdertyd moet die verskil tussen $\mathrm{Ou}$ en Nuwe Testament onthou word. Die openbaring het 'n geskiedenis deurgemaak en mag nie sommer geparalleliseer of genivelleer word nie. Dan word die toepassing vanself konkreet en aktueel omdat gelet word op die heilshistorie, op die kerk, op die amp, op die verbond (Van der Waal, 1974:234).

Samevattend: die Bybel self laat nie toe dat dit met 'n eksemplariese uitlegmetode (eksemplarisme) benader word nie en nieteenstaande kritiek, bly dit die verdienste van die voorstanders van die sogenaamde 'heilshistoriese metode' dat hulle in die veertigerjare ons oë oopgemaak het vir die eie aard van die Godsopenbaring.

\section{HEILSHISTORIESE PREDIKING}

\subsection{Die term heilshistoriese prediking}

Daar kan verskil word oor die term heilsgeskiedenis of heilshistorie. Van der Waal (1968:11) verwys na Grosheide se beswaar dat die woord heil in die term heilshistorie te 
veel die mens in die middelpunt stel. Dit kan die indruk wek asof dit in die geskiedenis in die Bybel in die eerste plek gaan oor die redding van die mens. Hierdie beswaar dra gewig, want dit gaan in die geskiedenis in die Skrif allereers oor wat God aangaande homself openbaar en in die tweede plek oor die vraag watter plek die mens in hierdie openbaring kry.

Bowendien wys Trimp (1986:37-46) daarop dat die term heilshistories uiters kwesbaar is. Dit is geen spesifiek gereformeerde term nie, maar word deur verskillende teologieë elk met sy eie inhoud gevul en so selfs hedendaags deur die Bevrydingsteologie gebruik. Wanneer die geskiedenis van die bevryding van die Jode in die ervaring van die swart mense ingebring word, dan begin vir hulle hulle heilsgeskiedenis (Trimp, 1986:46).

Die beste sou wees om soos Lion-Cachet (1989:20) van die gedagte uit te gaan dat ons in die Ou Testament - soos in die res van die Skrif - met openbaringsgeskiedenis te doen het, die geskiedenis van God se selfopenbaring. Nietemin word die term heilshistories hier tog gebesig ter wille van die historiese band met ' $n$ bepaalde groep predikante in die Gereformeerde Kerken in Nederland se beklemtoning in die veertigerjare. Daardie beklemtoning het immers 'n blywende merk op Gereformeerde prediking gelaat.

Die heilshistoriese preekmetode soos beskryf onder punt 2 kan kortliks s6 saamgevat word: heilshistoriese prediking is prediking wat erns maak met die feit dat die Bybel nie 'n bundel los verhale oor geïsoleerde geskiedenisse bevat nie. Hierdie metode wil die Bybel lees as die verhaal van God wat vanaf die paradysbelofte besig is om in Christus na sy volk te kom en wat op hierdie moment deur die verhoogde Christus oor kerk en wêreld regeer (Trimp, 1986:68).

Die metode ontken nie die voorbeeldkarakter van die Bybelse verhaal nie, maar wil dit op die regte wyse vir die hedendaagse gemeente tot voorbeeld stel.

\subsection{Besware teen die heilshistoriese preelometode}

Dit was veral Greidanus (1970:174 e.v.) en Trimp (1986:74 e.v.) wat verskillende besware teen die heilshistoriese benadering na vore gebring het. Die vernaamste word genoem. 


\subsubsection{Skematisme}

Die voorstanders van die heilshistoriese benadering wou in elke Skrifgedeelte aanwys tot waar God met sy heilswerk in Christus gevorder het. Hierdie benadering gaan van die verkeerde veronderstelling uit asof daar altyd 'n reglynige voortgang in die heilsgeskiedenis is. Onvermydelik het dit gelei tot skematisme: heilshistoriese preke het telkens daarin verloop dat die groot heilsfeite opgesom is. Dit kan nie ontken word dat daar bepaalde tydsmerkers in God se werk is nie, maar Greidanus (1970:174 e.v.) wys daarop dat dit onmoontlik is om altyd presies te kan aantoon tot op watter moment God se werk gevorder het. Hy toon met verskillende voorbeelde uit Schilder se driedelige werk, Christus in zijn lijden, aan hoe hierdie kunsmatige raamwerk gelei het tot skematisme en selfs spekulasie en objektivisme. Die Bybelse geskiedenis is geskiedenis waarin daar heel dikwels juis geen voortgang te sien is nie. Trimp (1986:101) sê: "Er zitten veel herhalingsoefeningen, strafexpedities, terugtrekkende bewegingen en menselijk falen in". Hoewel, vanuit God se raadsplan beskou, daar 'n voortgang na Christus toe is, kan gebeurtenisse in die heilsgeskiedenis nie altyd chronologies gerangskik word nie.

Strydom $(1989: 5,50)$ wys daarop dat op dié wyse die spesifieke boodskap van die historiese teks juis nie aan die woord kom nie en beklemtoon dat aan die gevaar van hierdie skematisme alleen ontkom word indien onthou word dat God se geskiedenis met die wèreld verbondsgeskiedenis is, dit is die geskiedenis van God se omgang me1 mense. In die omgang moet die mens by herhaling gehoorsaamheid leer.

\subsubsection{Verenging van die begrip exempel}

Van Trimp (1986:74 e.v.) se indringendste kritiek is dat Holwerda die begrip exemplum ( = voorbeeld) versmal het en mede as gevolg daarvan onjuis gehanteer het. Volgens Holwerda $(1953: 84,85)$ is "een exempel én uit een serie gelyksoortige dingen", en "mis dit alle historiese kleur". Trimp (1986:76) betoog egter dat die woord 'n veel wyer betekenisveld het. Daarom kan dit met goeie reg verdedig word dat die geskiedenis wel 'eksemplaries', dit wil sê illustratief is, of bemoedigend of waarskuwend.

Die Latynse stam waarvan exempel kom, ex-imo, beteken uit-neem. 'n Goeie voorbeeld van wat uit-neem inhou, kry ons byvoorbeeld by die koringgradeerder. Laasgenoemde neem met sy instrument 'n monster uit die sak met koring en bepaal so die graad van die hele vrag. So kan exempel ook die betekenis kry van 'n waarskuwende voorbeeld of 'n navolgenswaardige voorbeeld. Die Latynse exemplum kan weergegee word met modeh, origineeh antesedent, patroon, nabootsing, kopie, afdruk, portret, illustrasie. 
Trimp (1986:86) meen verder dat dit jammer is dat daar nie in die debat uit 1941 meer geluister is na Luther en Calvyn nie. Uit Luther se prediking kon geleer word dat die "unieke heilshistorische situaties als zodanig niet uitsluiten een exemplarische funktie van de daarin optredende personen. Het hangt er maar van af hoe de verbinding tussen hen en ons in de prediking tot stand gebracht wordt" (vgl. bl. 84).

Trimp (1986:88) verwys na klagtes van D. van Dijk in 'n weekblad Pro Ecclesia dat Calvyn se toepassings soms willekeurig was en meen dat daar ongetwyfeld by Calvyn ontsporings was. Nietemin is hy oortuig dat sy uitgangspunt gesond was: "... de historische vertelling heeft betrekking op ons, omdat wij, evenals de Israelieten destijds, leven onder de eniggeboren Zoon van God. Wij staan met het volk van het oude verbond in een kerk en voor dezelfde God". Hiermee het Calvyn grondslae gelê waarop die gereformeerde prediking oor die verhalende stof nog steeds kan voortbou. Oorgevoeligheid vir die woord exemplum mag ons nie verlei om die eg Skriftuurlike hantering daarvan by Calvyn mis te kyk nie (Trimp,1986:88).

Trimp (1986:78) betreur dit dat die woord eksemplaries gebruik is om te verwys na 'n illustratiewe en atomistiese gebruik van die teks. Hy meen selfs (1986:78) dat ds. J. Douma in die veertigerjare reg was toe hy in die toentertydse debat exemplaries geinterpreteer het in die betekenis van "op de praktijk der godzaligheid gericht."

Die Bybelse verhale het wel deeglik ' $n$ voorbeeld-funksie. Die negatiewe betekenis wat deur die jare aan die begrip eksemplaries begin kleef het, moet verdwyn.

\subsubsection{Beklemtoning van die heilshistorie ten koste van die heilsordelike element}

Om te bepaal hoe die mens in die preek ter sprake gebring moet word, moet daar 'n bewustheid wees vir die 'heilsordelike' element in die heilshistoriese prediking. Trimp (1986:94) beweer dat die gevaar waarteen die voorstanders van die heilshistoriese metode gewaarsku het, naamlik dat die heilsgeskiedenis in 'n heilsordelike kategorie getransponeer word, reg was. Wie dit doen, maak die heilsgeskiedenis tot 'n simboliese uitbeelding van die persoonlike lewensgeskiedenis wat saamtrek in 'bevinding' of 'belewing' of 'ervaring'. Hiervolgens moet gelowiges almal hulle Pniël of Roepersfontein (Simson), of Pinkster belewe. Volgens Trimp (1986:95) misgis Holwerda hom egter terdeë as hy sê dat elke Bybelfiguur sy plek en funksie in die heilsgeskiedenis het, terwyl die heilsorde vir almal dieselfde is: die bekering as begrip is oral eenders. In die heilsgeskiedenis bestaan so ' $n$ bekering nie; by Abraham is die roeping, die bekering, die heiliging en volharding anders as by Dawid, by die een apostel anders as by die ander. 
Neem as voorbeeld die verskil tussen die bekering van Matteus die tollenaar (Mat. 9:9) en van Saulus (Hand. 9:6 e.v.). Die liefde van God is dieselfde vir almal, maar in die loop van die geskiedenis en by verskillende mense kom dit in 'n rykdom van gestaltes na vore.

\subsubsection{Onduidelikheid hoe die mens in die prediking na vore moet kom}

Jonker (1976:65 e.v.) noem dit 'n swakheid van die voorstanders van die heilshistoriese prediking in die Gereformeerde Kerke dat hulle nie altyd kon duidelik maak hoe die mens dan wel in die preek ter sprake moet kom nie omdat preke daardeur beheers word dat die lyn na Christus (soms geforseerd) aangetoon moet word.

By Holwerda (1953:90) het die uitdrukking ontstaan: "Die Christus moet verkondig word en nie die Christen nie". Dit was natuurlik gemik teen allerhande subjektivistiese en mensgesentreerde preke, waarin die psigologiese die hoofklem gekry het en die heilshistoriese verband glad nie ter sprake gekom het nie. Trimp (1986:96) wys egter op die gevaar van wat hy noem die "oorbeligting van die voortgang'en die onderbeligting van die "omgang'". Daarmee bedoel hy dat die voorstanders van die heilshistoriese metode uitsluitlik wou vra na die betekenis en taak van so 'n bepaalde figuur uit die heilsgeskiedenis vir die werk van God en Christus. Dit ag Trimp (1986:96) "volstrekt in strijd met de struktuur van Gods verbond en een verwerplike negatie van het werk van Christus en de Heilige Geest in dat verbond". Die Bybel laat ons tog sien hoedat God onderweg na Christus sy volk lei en hoe die volk in konkrete dade daarop reageer. Die gebeurtenisse toon ons wie God is, wie die mens is en hoe God wil he dat die mense hulle moet gedra. Daarom is dit moontlik om mense en gebeurtenisse as voorbeelde te gebruik sonder om die historiese verbande en die voortgang van die tyd te verwaarloos.

Daar mag nie, sodra die predikant in sy preek konkreet word en die mens met sy geloofsworstelinge of ongehoorsaamheid ter sprake kom, aan so 'n preek die etiket gegee word van 'mensgerig' of 'eksemplaries' nie. Wie oor die Christus praat, hoef oor die Christene met hulle konkrete lewenstryd nie te swyg nie (Bijzet, 1988:12).

\section{HEILSHISTORIES-VERBONDSMATIGE PREDIKING AS KORREKTIEF OP HEILSHISTORISME EN EKSEMPLARISME}

Die voorstanders van die heilshistoriese benadering se standpunt was dat daar in die prediking oor Bybelfigure steeds met die 'voortgang' van die heilsgeskiedenis rekening gehou moet word. Daardeur is die konkrete ryk geskakeerde 'verbondsomgang' van 
God met sy volk dikwels oor die hoof gesien. Aan die ander kant wou die eksemplariese rigting die mens ter sprake bring. In die proses is die mens dan meestal losgemaak uit die verband van die heilsgeskiedenis waarin die Bybel self so 'n mens laat optree. As korrektief op albei bogenoemde benaderings stel Strydom (1989:38 e.v.) die verbondsmatige benadering voor.

\subsection{Die term verhondsmatige prediking}

Verbondsmatige prediking word deur Strydom (1989:44) raak omskryf as hy sê: "Aangesien die verhouding tussen God en mens 'n verbondsverhouding (kursivering N.D.) is (monopleuries in sy ont-staan en dupleuries in sy be-staan), is dit onontwykbaar dat die verbond die integreringsnorm sal uitmaak in die prediking van die verhalende gedeeltes, maar trouens ook vir die ander genres in die Skrif." Verbondsmatige prediking laat die eie aard van die Skrif as verbondsboek tot sy reg kom.

\subsection{Die verbond as hemeneutiese sleutel}

Trimp (1986:38-40) het die aandag daarop gevestig dat die Bybelse geskiedenis ' $n$ eenheid vertoon en ook as 'verbondsgeskiedenis' getipeer kan word. Strydom (1989:24) verwys daarna dat Calvyn al ingesien het dat al die boeke van die kanon saamgebind word deur die groot tema van die verbond, wat dwarsdeur dieselfde bly, al verskil die beơiening daarvan. Dit is van groot belang dat raakgesien word dat die struktuur van die Ou en Nuwe Testament ooreenstem: die Ou Testament praat van die komende Christus, die Nuwe Testament van die gekome Christus en gryp voortdurend terug na die groot temas van die Ou Testament. Dwarsdeur die Ou en Nuwe Testament is dit steeds die drie-enige God wat in sy handelinge met die mens na vore tree.

Strydom (1989:58) beklemtoon dat hy nie die verbond "as dié hermeneutiese prinsipe" probeer voorhou nie, maar "as 'n hermeneutiese sleutel" wat in samehang met die belangrike teologiese grondmotiewe gelees, en binne die wye perspektief van die koninkryk verstaan moet word. Binne hierdie konteks word die goue draad van die verbond wat deur al die letterkundige genres van die Ou Testament, en uiteindelik tot by Openbaring 22 loop, sigbaar. Waar die verbond deur die prediker as sleutel gebruik word, kan op 'n ongeforseerde wyse aangewys word wat God se handeling in die besondere gedeelte is, maar ook hoe die mens daarop reageer. So kan 'n eensydige klem op dit wat God doen, of dit wat die mens doen, voorkom word. In verbondsmatige prediking kom sowel die heilsbemiddelende inisiatief van God tot sy reg as die 
verantwoordelikheid van die mens wat op God se handelinge moet antwoord (Strydom 1989:43). So sal prediking nie mensgesentreerd, psigologiserend, spiritualiserend, moraliserend en tipologiserend, soos in die eksemplarisme, wees nie.

Strydom (1989:52) wys daarop dat die demonstratiewe betekenis van 'n bepaalde Bybelfigur wat in gehoorsaamheid of ongehoorsaamheid aan die verbondswoord gehandel het, in die preek na vore gebring moet word: nie op so 'n wyse dat weer teruggeval word in 'n verlammende stuk moralisering nie, want dit is immers die verbondstrou van Gód en die geduldige werk van die Gés (ook reeds in die Ou Testament) wat 'n bepaalde Bybelfiguur laat gehoorsaam het én dit is die verwerping daarvan wat hom bring tot verset en ellende.

As daar regtig verbondsmatig gepreek word, hoef daar geen spanning te bestaan tussen 'heilshistories' en 'eksemplaries' nie, want dan lè die gehoorsame exempel ingebed in die ewige verbondstrou van God en die werking van sy Gees, en die óngehoorsame in die verwerping van God se verbondstrou. Só word die dilemma heilshistorieseksemplaries opgehef - maar dan enkel en alleen vanuit die gesigshoek van die verbond (Strydom, 1989:52; kursivering N.D.).

\section{ENKELE RIGLYNE}

\subsection{Ooreenkoms in struktuur, maar verskil in situasie}

Die riglyne wat Gootjes (1987:977 e.v.) aan die hand doen onder die titel "Ons ten voorbeeld geschied", is waardevol. In die besondere artikels handel Gootjes eers oor Skrifgedeeltes waarin God se handelinge in die geskiedenis vir ons tot voorbeeld moet dien, byvoorbeeld Levitikus 9 en 10. Daar word beskryf hoe God, toe die tabernakel in gebruik geneem is, die brandoffer met vuur uit die hemel verteer het. Gootjes (1987:1) laat sien wat die karakteristieke van God se daad is wat vir ons tot exempel dien.

Die wyse waarop Gootjes die karakteristieke van God in 2 Samuel 6 na vore bring, (God dood Ussa as hy aan die ark raak), is leersaam. Hy (1987:2) wys daarop dat die exempel nie lê in Ussa se persoon nie, maar in die "dodende God.en wat Hij daarmee van zichzelf openbaart" (1987:2). Die verbond as hermeneutiese sleutel, soos deur Strydom aangewys, word inderdaad deur Gootjes (1987:3) gehanteer as hy gedeeltes bespreek waarin die handelinge van die mens vir ons tot voorbeeld moet dien. "Een menselijke handeling kan niet op zichzelf tot een voorbeeld zijn. Dat wordt menselijk handelen pas wanneer het in verband met Gods Woord en werk voorkomt."

Verhelderend beklemtoon Gootjes telkens dat die ooreenkoms tussen die Bybelse 
figuur se optrede en ons optrede vandag in die 'strukturele' ooreenkoms gesoek moet word en nie in die 'situasionele' nie, en dat die voorbeeldfunksie van so 'n gedeelte sy grond in God se handeling het. Gootjes (1987:3) neem Genesis 15 as voorbeeld: Abram vertrou op God se belofte van 'n seun en 'n talryke nageslag. Paulus stel in Romeine 4 Abraham se geloof vir ons tot 'n voorbeeld. Wat situasie betref, is daar tussen ons en Abraham geen enkele ooreenkoms nie: ons leef in 'n ander tyd as Abraham; ons is ook nie stamvaders van die volk aan wie die Messias beloof is nie.

Daar bestaan wel 'n strukturele ooreenkoms. Ons moet net soos Abraham op 'n belofte vertrou wat, menslikerwys gesproke, onmoontlik is. God reken egter dié een regverdig wat glo in wat Hy beloof het: regverdiging in die gekome Christus.

\subsection{Werkstadia in preekvoorbereiding}

Trimp (1986:1 e.v.) se "Werkmethode bij de voorbereiding van prediking over oudtestamentische verhalende stof", het vir die praktyk van preekmaak uit die historiese gedeeltes van die Skrif baie betekenis. Trimp onderskei vier werkstadia in die voorbereiding van die preek, naamlik die analise, die sintese, die bediening, die toetsing.

\subsubsection{Die analise}

Onder die analise verstaan Trimp twee dinge:

- Eerstens moet die betekenis van die woorde en sinne op die gebruiklike wyse vasgestel word.

- Tweedens moet die plek en spraak (= profiel) van die verhaal binne die onmiddellike verband vasgestel word. Die eksegeet moet in die verhaal staan en terugkyk, sywaarts kyk en ook vorentoe kyk.

Om terugwaarts te kyk, beteken dat die historiese en saaklike agtergrond van die vertelling in die konteks van die Bybelboek, asook in die hele Bybel opgespoor word. As daar byvoorbeeld gepreek word oor een van die konings van Juda (bv. Hiskia), kan die standaard vir die koningskap soos God dit in Dawid se bewind getoon het ( 2 Kon. 18:3), nie geïgnoreer word nie.

Om sywaans te kyk, beteken om die verhaal te probeer plaas in die kultuur en geskiedenis van die besondere tyd waarin dit afspeel. As daar byvoorbeeld gepreek word oor 
die afval van die konings in Israel, moet nagegaan word hoe die politieke en militêre situasie was op die tydstip waarvan die teks vertel (bv. 2 Kon. 13:3). Tegelyk moet gevra word waarom die afgodery en beeldediens so 'n aantrekkingskrag vir Israel gekry het ( 2 Kon. 17:7 e.v.).

Om vorentoe te kyk, moet gevra word na die tendens van die verhaal, en ook van die Bybelboek. Wat wil die Here hier bereik op kort en langer termyn? Wat doen die mense teenoor God? Oor God se bedoeling en die teenwerking van die mense deur die geskiedenis heen, word baie in die Bybel self gepraat - vergelyk byvoorbeeld Deuteronomium 32, Josua 24 ensovoorts (vgl. Schilder, 1983:137 e.v.).

\subsubsection{Die sintese}

Die sintese bestaan daaruit dat die openbaringsgehalte van die teks bepaal word. Twee vrae help om die sintese te bewerkstellig, naamlik:

- Wat maak die verhaal duidelik aangaande God, sy werk as Vader, as Seun en as Heilige Gees.

- Wat vertel die verhaal omtrent die mens wat in die verbond met God mag en moet lewe. Is hy byvoorbeeld getrou, of juis nie?

Die resultaat van hierdie sintese kan nou wees die vasstel, en ook 'fyn-stel', van die heilshistoriese strekking van die verhaal. Vir hierdie 'fyn'-stelling is die vrae wat Holwerda (1953:111) geformuleer het, nog steeds bruikbaar. Hy beveel aan om die teks op die volgende vier punte te ondervra:

- Die reeds van die openbaring in die Ou Testament,

- die nog nie van die Nuwe-Testamentiese vervulling,

- die nie meer nie van die Ou-Testamentiese skaduwee in die Nuwe Testament,

- die nog steeds van die Ou Testament in die Nuwe Testament.

\subsubsection{Die reeds}

Ook in die Ou-Testamentiese bedeling was die omgang met God 'n ryk omgang deur die Middelaarsdiens van die Seun van God en deur die werk van die Heilige Gees. Wie eerder geleef het, het nie daardeur 'n armer omgang met God gehad nie. Noag het baie van God se werk verstaan, mér as byvoorbeeld Sedekia, (vgl. Gen. 6-9 en 2 Kon. 24:19.) Abraham se vreugde by die geboorte van Isak was vreugde ter wille van Christus (vgl. Joh. 8:56.) 


\subsubsection{Die nog nie}

Die dissipels het meer van die heerlikheid van die Vader gesien (Joh. 1:14) as Moses (Eks. 33:19); vergelyk Lukas 10:23,24. Die rou oor die dood van Aäron (Num. 2:29) het geroep na die geloofsvreugde oor die onverganklike priesterskap van Christus (Heb. 7).

\subsubsection{Die nie meer nie}

Israel moes rein en onrein diere onderskei. So moes hulle in die konkrete praktyk van die daaglikse lewe leer wat God se plan met sy volk is en hoe die volk op God se heilige pad moet gaan (Deut. 14:3-21). Hierdie wyse van godsdiens is vir ons nie meer van toepassing nie (Hand. 10:9 e.v.; Gal. 2:11 e.v.; Kol. 2:16 e.v.; Heb. 8-10). Die kern is egter nog van krag (vgl. art. 25 NGB): 'n heilige lewe deur die Gees van Christus.

\subsubsection{Die nog steeds}

Die 'vrees van die Here' is 'n verbondseis, wat in die tyd waarin God se openbaring in Christus en deur die Gees toegeneem het in intensiteit, op die gelowige 'n baie swaarder verpligting le (vgl. Heb. 10:26-31). Die blydskap oor God se verlossingswerk tydens die uittog uit Egipte (Eks. 15) moet des te sterker gevind word by die NuweTestamentiese gemeente wat die Nagmaal vier.

\subsubsection{Die bediening}

Met die sogenaamde 'meditasie' of 'homiletiese eksegese' word gevra na die konkrete gesag van die teks binne die konkrete gemeente wat bedien word.

Die noodsaak dat die 'historiese distansie' oorbrug word, het die hoofaksent. Laasgenoemde kan in 'n paar onderdele verdeel word, naamlik:

- Die band tussen toe en nou. Hierdie verband word genoem die kontinue tussen toe en nou. Hierdie kontinue sien ons op twee vlakke, naamlik dié van God en dié van die mens.

- Die kontinue tussen toe en nou op die vlak van God. Hier gaan dit daaroor dat God se Woord en werk dieselfde gebly het. In sy Seun het Hy aan ons sy definitiewe 
openbaring gegee, maar die openbaring vertoon kontinuïteit met sy openbaring in die ou bedeling (vgl. Heb. 1:1,2). Soos Hy toe was (by Abraham en Moses, ens.), so is Hy en sal Hy wees. Op hierdie wyse moet ons die ou verhale van die Bybel lees. Die God van die vaders is die lewende God. Hy is aktueel en daarom het die ou verhaal, 'n aktuele strekking. Alleen so maak ons erns met die Bybel as boekstawing van die geopenbaarde Woord van God.

- Op die vlak van die mens voor God kan ook gepraat word van 'n konstante deur die eeue heen. Ons herken onsself in dominante aksies en reaksies van die persone wat in die Bybelse verhale optree. In sy strewes, behoeftes, verdriet en vreugdes vertoon die mens die eeue deur dieselfde kenmerke as die mens van vandag.

- Die distansie tussen toe en nou: geografies, temporeel, kultureel, polities ensovoorts. Die 'nog nie' en die 'nie meer nie' moet gekonkretiseer word. Helderheid omtrent hierdie distansie voorkom die historiese gelykteken en die vervlugtiging.

- Naas die sentrale sin en skopus wat elke verhaal het, is daar ook elemente wat daaraan ondergeskik is. By die eietydse vertelling spreek hierdie ondergeskikte elemente tot die gemeente van vandag. Wie die distansie binne die kontinue respekteer, kan met veiligheid ook hierdie elemente van veralgemening ter sprake bring. Trimp verwys na Schilder (1983:1-37) vir voorbeelde.

- Die keuse van sulke elemente en die wyse van aanbieding daarvan het alles te doen met die situasie of die konteks van die gemeente. Ons moenie in die Bybel na parallelle gaan soek nie. Ons moenie die Bybel gaan deursoek vir tekste wat volgens die maatstaf van ons belewings- of gevoelsbehoeftes geselekteer word nie, maar ons moet wel met ons eie vrae (die vrae van ons tyd en van ons eie lewe) luister na die Bybel. Op dié manier kan dit kom tot egte 'horisonsamesmelting': die historiese verhaal van God se handelinge blyk ook ons wèreld (insluitende ons ervaringswereld) te omvat: Romeine 15:4; 2 Timoteus 3:16,17.

\section{$5.3 \quad$ Toetsing}

Die laaste stadium van die preekvoorbereiding is die toetsing van die resultaat. Wanneer die grammatikale sin, die Skriftuurlike strekking en die ondergeskikte elemente van die vertelling onder woorde gebring is binne die konteks van die gemeente, moet die toetsvraag gestel word of hierdie elemente mekaar nie weerspreek nie en of hulle mekaar steun en 'n harmoniese geheel vorm. Juis hier sal eenvoud en duidelikheid die kenmerk van die ware wees. 


\section{SLOTSOM}

Alleen as prediking van so ' $\mathrm{n}$ aard is dat dit volle erkenning gee aan die eiesoortigheid en historisiteit van die Ou Testament in sy eenheid met die Nuwe Testament, dat dit rekening hou daarmee dat God homself steeds ryker openbaar in Jesus Christus, en dat dit verbondsmatig is in die sin dat dit in berekening bring dat dit verbondsgeskiedenis is waarin God sy liefde konkreet vir sy konkrete verbondsvolk ontsluit en dit konkrete wederliefde van sy bondgenote eis, kan dit gesagvolle prediking wees en sal dit die kerk opbou in die allerheiligste geloof. Anders word die prediking afgewater en die volk van God met klippe gevoed.

\section{BIBLIOGRAFIE}

BIJZET, FJ. 1988. Wat mag ons van 'n preek verwag? Mededelingsblad van die Vrije Gereformeerde Kerk. Pretoria 19(21):8-13. Nov.

D'ASSONVILLE, V.E. 1961. Eksemplariese prediking ... 'n gevaar wat ons kansels bedreig. Die Kenkblad, 64(1611):13-16.

D'ASSONVILLE, V.E. 1962. Die prediking oor historiese stof in die Skrif. Die Goue Kandelaar, 1(1):2330 .

D'ASSONVILLE, V.E. 1976. Die dwaasheid om te preck. Johannesburg: De Jong.

DE VRIES, W.G. 1983. Bijlage: K. Schilder. lets over de eenheid der 'Heilsgeschiedenis' in verband met de prediking. Het ene woord en de vele sekten. Goes : Oosterbaan \& le Cointre. p. 154 194.

GOOTJES, N.H. 1987. Ons ten voorbeeld geschied. De Reformatie, 62(48):977-978; 62(49):997.998; 63(1):1,2; 63(2):21-23.

GREIDANUS, S. 1970. Sola Scriptura. Kampen : Kok.

GROSHEIDE, F.W. 1929. Hermeneutiek. Amsterdam : Van Bottenburg.

HOLWERDA, B. 1953. De heilshistorie in de prediking. Begonnen hebbende van Mozes .... Terneuzen : Littooij.

JONKER, W.D. 1976. Die Woord as opdrag - gedagtes oor die prediking. Pretoria : NG Kerkboekhandel.

KAPTEIJN, K.J. 1988. Heilshistoriese en eksemplariese prediking. Woord en Wandel, 17(6):101-105; $17(7): 121-125$.

LION-CACHET, F.N. 1989. Die prediking oor die historiese stof van die Ou Testament. In die Skriflig, 23(89):20-34.

ODENDAAL, D.H. 1989. Covenant - the centre of the Old Testament? Ned Geref. Teologiese Tydskrif, $\mathrm{XXX}(2): 143-151$.

SCHILDER, HJ. 1974. Modern exemplarisme I en II. De Reformatie, 50(10):41-42; 50(11):81-82.

SCHILDER, K. 1983. Het Schrift dat niet verslijt. Opstellen over bet Oude Testament. Kampen : Van den Berg.

STRYDOM, M.C. 1989. Eksemplaries? Heilshistories - Voortsetting van 'n gesprek. Bloemfontein VCHO.

TRIMP, C. 1986. Heilsgeschiedenis en prediking. Hervatting van cen onvoltooid gesprek. Kampen : Van den Berg.

TRIMP, C. 1986. De preek. Een praktisch verhaal over het maken en houden van preken. Bijlage 1: Werkmethode bij de voorbereiding van prediking over oudtestamentische verhalende stof. Kampen: Van den Berg. 
VAN DER WAAL, C. 1974. Enkele opmerkings oor tipologie. Ned. Geref. Teologiese Tydskrif, XV(1):225-235.

VAN DER WAAL, C. 1968. Rondom de prediking. Pretoria: 11.

VAN DER WALT, JJ. 1989. Teologiese tipologie: 'n Homiletiese sleutel vir die prediking van die Ou Testament. In die Skriflig, 23(1):53-61.

VAN "T VEER, M.B. 1944. Christologische prediking over de historische stof van het Oude Testament. (In Schippers, R. Van den dienst des Woords. Goes : Oosterbaan \& le Cointre. p. 117-168.) 